\title{
Prevalence of peste des petits ruminants in goats in North-East India
}

\author{
V. Balamurugan - Sutopa Das • D. S. N. Raju $\cdot$ Indirani Chakravarty $\cdot$ \\ M. Nagalingam - D. Hemadri - G. Govindaraj • N. Ibotombi Singh • \\ Keduzol Ltu • Maitryee Devi · K. Sharma • M. R. Gajendragad • \\ H. Rahman
}

Received: 4 June 2014/ Accepted: 29 October 2014/Published online: 11 November 2014

(C) Indian Virological Society 2014

\begin{abstract}
The present study describes prevalence of peste des petits ruminants (PPR) virus infection in goats in various parts of North-East (NE) India by screening of suspected serum samples collected during outbreak investigation and random samples during 2013-2014 survey. A total of 391 serum samples (318 random and 73 outbreak/suspected) were collected from 28 districts in 7 states (Meghalaya, Assam, Manipur, Nagaland, Arunachal Pradesh, Tripura and Mizoram) of NE India. Serum samples were screened for PPRV-specific antibodies by using PPR monoclonal-antibody based competitive ELISA. Analysis of 391 serum samples indicates that an overall seroprevalence of $17.90 \%$ [CI $95 \% 14.40-22.00$ ] in goats \{45.2\% in suspected [CI $95 \% 34.32-56.58$ ] and $11.63 \%$ in random [CI $95 \%$ 8.56-15.63] samples $]$ in NE India. As
\end{abstract}

V. Balamurugan and Sutopa Das have equally contributed to this work.

V. Balamurugan $(\bowtie) \cdot$ D. S. N. Raju $\cdot$ M. Nagalingam .

D. Hemadri - G. Govindaraj - M. R. Gajendragad - H. Rahman Indian Council of Agricultural Research (ICAR)-National Institute of Veterinary Epidemiology and Disease Informatics (NIVEDI), Hebbal, Bengaluru 560 024, Karnataka, India e-mail: balavirol@gmail.com

S. Das · I. Chakravarty · M. Devi · K. Sharma

Department of Veterinary Microbiology, College of Veterinary

Science, AAU, Khanapara, Guwahati, Assam, India

N. Ibotombi Singh

Department of Veterinary and Animal Husbandry Services, Imphal, Manipur, India

\section{K. Ltu}

Disease Diagnostic Laboratory, Department of Veterinary and Animal Husbandry, Veterinary Hospital, Kohima, Nagaland, India expected prevalence was high in outbreaks vis-à-vis random samples. The random survey results $(11.63 \%)$ has specific implication in epidemiological perspectives, since it highlights the exact PPR prevalence under natural situations, where the subclinical, in apparent or nonlethal or recovery of infection was suspected in goats, as samples were collected from unvaccinated animals. It also warrants appropriate control measures against PPR in NE region to prevent spread of infection besides widespread presence of the disease in rest of India.

Keywords PPRV · Antibodies · Prevalence · Sheep · Goats $\cdot$ North-East India

\section{Introduction}

Peste des petits ruminant (PPR) is a World Organization for Animal Health (OIE) notifiable and economically important transboundary viral disease of sheep and goats. It is a highly contagious viral disease of domestic and wild small ruminants and is currently emerging to cause infections in camels [1]. The disease is characterized by pyrexia, ocular and nasal discharges, necrotic stomatitis, catarrhal inflammation of the ocular and nasal mucosa, enteritis, diarrhoea and bronchopneumonia followed by either death or recovery from the disease [3]. Mortality and morbidity of disease are high when occurring in naive sheep and goat populations. PPRV primarily affects goats and sheep and cattle and buffaloes are asymptomatically infected with seroconversion while other wild ruminants and camels may express clinical signs and mortality [1]. The PPR, being the plague of goats and sheep, poses heavy threat to the national economy of the countries, where the disease is endemic. The causative agent, PPR virus (PPRV) belongs 
to the Morbillivirus genus and there is a single serotype of PPRV, but genetically grouped into four distinct lineages (I, II, III, and IV) based on partial sequence analysis of Fusion (F) gene [9]. Spread of disease to a number of new countries in Africa and Asia with involvement of various lineages of PPRV is a cause of global concern especially recent introduction of Asian lineage in some African countries and presence of PPR in Europe through Western Turkey $[1,3]$. This transboundary nature of the disease is one of the main constraints in augmenting the productivity of small ruminants in enzootic regions.

In India, PPR was first recorded in 1987 from Tamil Nadu and it continues to be present in the Southern peninsular India until 1994 [9, 10]. Later, a number of PPR outbreaks were reported from the northern states of India $[3,10]$. Now, PPR is enzootic in India as outbreaks occur in small ruminants regularly throughout the country [3, 10] and is a major constraint in small ruminant production incurring huge economic losses in terms of morbidity, mortality, productivity losses with trade restriction $[3,10]$.

Information on the prevalence of PPRV antibodies in sheep, goats, cattle, buffaloes, camels, wild ruminants etc., is available from a number of countries in which the disease is reported including India [1, 3, 4, 6, 10, 14]. Majority of the reports from India indicated only the regional data from various states about the PPR seroprevalence in small ruminants and bovine [4, 6, 10, 13]. In India, several outbreaks go unrecorded due to under-reporting/non-reporting and plenty of PPR outbreaks have occurred in the past and are now occurring regularly throughout the country. Even though India is endemic to PPR, some states especially North-East states (NE zone) either free from disease or have very few reports. PPR is of increasing importance and likely to extend its geographic distribution especially in NE states, as PPR outbreaks have been reported in Assam [2, 3] and in Tripura [5, 8]. The geographical distribution of PPR in India has been widened quickly in recent times, which may be due to its economic importance, public and regulatory concerns and the availability of diagnostics. This study was undertaken with an objective of generating the baseline data on prevalence of PPRV antibodies in goats using random samples collected in seven NE states of India during 2013-2014 survey along with suspected samples collected during outbreak investigation with an aim to help in the implementation of proper disease control strategies such as vaccination in that particular geographical area.

\section{Materials and methods}

\section{Clinical samples}

Prevalence of PPR in goats investigated in this study was recorded from 28 districts in seven states (Meghalaya,
Assam, Manipur, Arunachal Pradesh, Tripura and Mizoram) of NE India. Serum samples of unknown antibody status [ $\mathrm{n}=318$-goats] were collected through All India Co-ordinated Research Project (AICRP) centres of animal disease monitoring and surveillance (ADMAS) as per the random sampling frame designed by the NIVEDI from various villages (where sheep and goats and other livestock were reared together and can be called as one epidemiological unit) in the selected districts in NE states during 2013-2014 survey. Since many villages lack sizeable goat population a criterion of minimum goats in a village was put for determining working sampling frame of the villages for the survey was prepared. Further suspected samples $[\mathrm{n}=73]$ collected during outbreaks investigations by our research team or by field veterinarians and submitted to NIVEDI were screened for PPRV-specific antibodies by using PPR competitive ELISA kit [12]. The collected serum samples during 2013-2014 survey and suspected samples (clinical blood and tissues samples) during outbreaks investigations (Table 1) were tested for PPRV antibodies/PPRV antigen/nucleic acid by using various serological and molecular assays including isolation study to confirm the outbreaks in goats as PPR.

\section{Serological and molecular assays}

PPR competitive ELISA and PPR sandwich ELISA (both kits were procured from IVRI, Mukteswar, India) was used for detection of PPRV antibodies and antigen, respectively as described earlier $[11,12]$. Samples with percentage inhibition (PI) of $\geq 40 \%$ were considered positive for the presence of PPRV antibodies. The viral RNA was extracted from the tissue filtrate by using RNAeasy kit (RNeasy ${ }^{\circledR}$ Minikit Qiagen Inc, Valencia, CA, USA), as per the manufacturer's procedures. RT-PCR was performed for the first strand synthesis using Thermo Scientific Revert Aid First Strand cDNA Synthesis Kit using random hexa primers. The $\mathrm{N}$ gene fragment was amplified from all the generated cDNA's of tissue samples by PCR using Taq DNA polymerase master mix (Ampliqon, Denmark) with PPRV N gene-specific primers as described earlier [7]. Further, for isolation of virus, the $25 \mathrm{~cm}^{2}$ culture flask containing Vero cell monolayer with $80 \%$ confluency, was infected with $1 \mathrm{ml}$ of processed tissue filtrate in DMEM media by adsorption method with change the media every alternative day and maintained for 6-8 days. Then, subculture of the cells (periodically up to 10 passage level) after every 8th day was carried out and maintained the cells till the observation of specific PPRV cytopathic effect (CPE).

Statistical analysis

The apparent prevalence and true prevalence were also estimated as per the following formula [15]. (i) Apparent 
Table 1 Details of the samples screened for peste des petits ruminants virus antibodies/antigen/nucleic acid in goats

\begin{tabular}{|c|c|c|c|c|c|c|}
\hline State & Name of districts & $\begin{array}{l}\text { Total no. } \\
\text { of samples } \\
\text { screened }\end{array}$ & $\begin{array}{l}\text { Positive in } \\
\text { Competitive } \\
\text { ELISA }\end{array}$ & $\begin{array}{l}\text { Apparent } \\
\text { prevalence } \\
(\%)\end{array}$ & $\begin{array}{l}\text { True } \\
\text { prevalence } \\
(\%)\end{array}$ & $\begin{array}{l}\text { Confidence } \\
\text { interval } \\
(95 \%)\end{array}$ \\
\hline \multicolumn{7}{|c|}{ Serum samples randomly collected } \\
\hline $\begin{array}{l}\text { Arunachal } \\
\text { Pradesh }\end{array}$ & $\begin{array}{l}\text { West Kameng, Lohit, West Siang } \\
\text { and Papum Pare }\end{array}$ & 32 & 5 & 15.62 & 15.45 & $6.87-31.76$ \\
\hline Assam & $\begin{array}{l}\text { Kamrup, Mongoldoi, Bongaigaon, } \\
\text { Nalbari, Udalgiri, Darrang, } \\
\text { Gorchuk,Guwahati, Barpeta, and } \\
\text { Dhubri }\end{array}$ & 105 & 19 & 18.09 & 18.17 & $11.91-26.55$ \\
\hline Manipur & $\begin{array}{l}\text { Ukhrul,Chandel, Thoubal, Imphal } \\
\text { East, Senapati, Bishnupur and } \\
\text { Chaurachandpur }\end{array}$ & 92 & 0 & - & - & - \\
\hline Meghalaya & $\begin{array}{l}\text { Jaintia Hills, East Khasi Hills and } \\
\text { Ribhoi }\end{array}$ & 34 & 2 & 5.88 & 4.72 & $1.63-19.09$ \\
\hline Mizoram & & 12 & 0 & - & - & - \\
\hline Nagaland & Kohima and Dimapur & 25 & 0 & - & - & - \\
\hline Tripura & West Tripura and Bishalgarh & 18 & 11 & 61.11 & 65.54 & $38.62-79.69$ \\
\hline \multirow[t]{3}{*}{ Sub-total } & - & 318 & 37 & 11.63 & 11.05 & $8.56-15.63$ \\
\hline & $\chi^{2}$ Value & & $70.30^{\mathrm{a}}$ & & & \\
\hline & Mean $\pm \mathrm{SE}$ & & & $36.71 \pm 0.016$ & $34.51 \pm 0.007$ & \\
\hline \multicolumn{7}{|c|}{ Suspected serum samples collected during outbreak } \\
\hline Meghalaya & Ribhoi & 4 & 0 & - & - & - \\
\hline Assam & $\begin{array}{l}\text { Kamrup, Mongoldoi, Nalbari, } \\
\text { Gorchuk, Guwahati, Darrang }\end{array}$ & 69 & 33 & 47.82 & 50.90 & $36.47-59.42$ \\
\hline Sub-total & & 73 & 33 & 45.20 & 48.02 & $34.32-56.58$ \\
\hline Total & & 391 & 70 & 17.90 & 17.95 & $14.40-22.00$ \\
\hline & Mean $\pm \mathrm{SE}$ & & & $32.99 \pm 0.05$ & $35.05 \pm 0.05$ & \\
\hline \multicolumn{7}{|c|}{ Suspected clinical samples collected during outbreak } \\
\hline & & $\begin{array}{l}\text { Samples } \\
\text { screened }\end{array}$ & $\begin{array}{r}\text { Positive in } \\
\text { S-ELISA }\end{array}$ & $\begin{array}{r}\text { Positive in } \\
\text { RT_PCR }\end{array}$ & - & - \\
\hline Meghalaya & Ribhoi & $\begin{array}{l}\text { Pooled } \\
\quad \text { tissues-6 }\end{array}$ & 0 & 2 & - & - \\
\hline \multirow[t]{2}{*}{ Assam } & $\begin{array}{l}\text { Kamrup, Mongoldoi, } \\
\text { Nalbari,Jorhat, Guwahati }\end{array}$ & $\begin{array}{l}\text { Pooled } \\
\text { tissues- } \\
25\end{array}$ & 2 & 7 & - & - \\
\hline & & Blood-6 & 0 & 2 & & \\
\hline
\end{tabular}

s-ELISA-sandwich ELISA, RT-PCR- reverse transcription-polymerase chain reaction

$S E$ Standard Error

${ }^{a}$ Represents significance $(\mathrm{p}<0.01)$ level

prevalence $=$ number of positive animals/number of tested animals. (ii) True prevalence $=$ apparent prevalence + (specificity -1$)] /[($ sensitivity + specificity $)-1]$. True prevalence rate was calculated based on the sensitivity and specificity of the c-ELISA employed in the study, which is having high relative specificity $(98.4 \%)$ and sensitivity $(92.4 \%)$ when compared with virus neutralization assay [12]. The estimation of confidence interval $(95 \%)$, Mean \pm SE and $\chi^{2}$ test were carried out as per standard statistical method using statistical analysis system (SAS) software version 9.3 package (SAS India Ltd., Mumbai).

\section{Results}

Detection of PPRV antibody

The percent positivity of PPRV antibodies in goats with apparent and true prevalence are presented in Table 1. Analysis of 391 serum samples from goat indicated overall prevalence of $17.90 \%$ in goats $(45.2 \%$ in outbreak samples and $11.63 \%$ in random samples). The percentage prevalence of PPRV antibodies in goats were 5.88, 18.09/ 47.82 (random/outbreak), 15.62 and 61.11 in Meghalaya, Assam, Arunachal Pradesh and Tripura, respectively. High 
percent prevalence $(61.1 \%)$ in goat from Tripura was observed in random samples with no prevalence in the states of Manipur, Nagaland and Mizoram. The PI values (ranges from 25 to 100) obtained in competitive ELISA from tested goat samples were classified as five categories. Most of the serum samples $(n=248)$ from goat showed PI values $<25$ reactivity in ELISA representing the negative. There were 24 samples falling in the range of PI between 40 and 60 PI (positive) and 26 samples in the range of PI between 60 and 80 PI (Weak positive) and 17 in the range of PI between 80 and 100 PI (Strong positive). Among the suspected outbreaks samples high percent prevalence (47.82 \%) was observed in Assam.

\section{Detection of PPRV antigen/nucleic acid}

On testing, of the clinical samples collected during outbreak investigations in Assam and Meghalaya states by sandwich ELISA, RT-PCR, showed none of the samples revealed specific PPRV CPE in the Vero cells, even after ten passages. The attempted isolation of virus in Vero cells was unsuccessful, which may be due to maintenance of the cold chain and degradation of the samples for isolation as the samples were transported from far place to the test laboratory. However, the detection of PPRV antigen and nucleic acid in the most of the clinical samples by N gene based RT-PCR assay and sandwich ELISA, confirming the outbreaks as PPR.

\section{Discussion}

Measurement of the PPRV antibodies in small ruminants in different geographical area of the country with varying agro-climatic conditions may be helpful in knowing the prevalence status under natural situation and in turn help in disease control measures/strategies for implementation of vaccination programme. Organized survey or investigation using random samples has not been conducted against PPR in NE India, except few isolated PPR outbreaks report in small ruminants. An outbreak was recorded in a government sheep and goat farm in Karbi-Anglong district, Assam with clinical disease in the forms of abortion and high fever, diarrhea and the disease was confirmation by serological test/assay in referral laboratory in IVRI, Mukteshwar with outbreak history of newly introduced Sirohi goats brought from Rajasthan [2]. Similarly, another outbreak recorded in government goat farm of Panbari in Dhubri district, Assam during 2010 [2].

The present investigation has provided baseline information on prevalence of PPRV antibodies in young and adult goats in situations where the subclinical, inapparent or nonlethal, or recovered infection status was suspected in different districts in various states of NE India during
2013-2014 preliminary survey, as vaccinations against the disease is limited and even not practiced in NE India.

Presence of PPRV antibodies in goats indicate the population was exposed to PPRV infection in naturally either directly or indirectly. This may be because the samples were collected from suspected cases during PPR outbreaks investigation and all the outbreaks were confirmed as PPR based on the serological and molecular diagnostic assay in this study. Balamurugan et al. [3] attributed greater PPR positivity in clinical samples from goats to the fact most of the suspected samples were from regions, which had larger goat population. Similarly Soundararajan et al. [13] reported a higher mortality rate among infected goats than sheep in a large organized farm, which too has larger goat population. Similarly in NE region also, mostly outbreaks occurred in goats, it may be due to trade or transport of goats from northen India to NE India. In general, NE states have a relatively small sheep and goats population and intermixing of these animals with the small ruminants (sheep and goats) population from the rest of the country is usually limited because of very narrow connecting passage [10].

However, prevalence of PPRV antibodies in adult goats is not always indicative of PPR infection, as there is always a high probability of these animals receiving vaccination once during a lifetime. The present seroprevalence of $45.2 \%$ in suspected cases concurrent with the other reports. Chavan et al. [6] reported an overall seroprevalence of PPR in goats of $46.01 \%$, with a range of 42.30-52.94\%, at different locations in the Parbhani region of Maharashtra. In northern India, generally goat-adapted virus circulation is there in the population, as most of the outbreaks from northern are more severe in goats than sheep. Movement of animals from northern India (where more population of goats than sheep) to the NE India are frequently happening for the trade purpose. These could be reason for the more outbreaks occurred in goats than sheep, as outbreaks samples were from goats. In a recent study from Tanzania, significantly more seropositive individuals were found among goats than among sheep (49.5 vs. $39.8 \%$; $p=0.02$ ), with an overall seroprevalence of $45.8 \%$ [14]. This variations in seroprevalence could be due to differences in sample size, age, prevailing management practices, humidity or season, etc., [10].

The results also showed that the PPRV antibodies prevalence in goats is associated with differential region (states) $\left(\chi^{2}=70.30, \mathrm{p}<0.01\right)$. This finding may be related to the increase in the incidence of the disease from 1995 onwards in northen India and 2010 onwards in NE India [3]; the disease is now enzootic in NE India in some pockets. It may be due to continuous surrounding of some of the NE states with PPR endemic countries like Bangladesh resulting in spread of disease in few endemic regions (states). Earlier, an outbreak of PPR occurred in Black Bengal \& their cross with Jamunapuri \& Beetal, in regional goat breeding Farm in Tripura during 
1997 with high morbidity (78.95\%) and mortality (45.79\%) and case fatality (58\%). The outbreak was observed after the introduction of Barbari goat procured from Makhdoom in north India and there was no dissemination of the epidemic among adjoining naive susceptible population of the district during the period of 49 days epidemic [8]. However, recently, PPRV isolated from an outbreak that occurred in sheep and goats at Tripura in the year 2012, revealed high degree of identity with Bangladesh isolates, which indicates the cross border movement of animals between the international borders of both the countries [5].

The $95 \%$ CI for the seroprevalence in goats in NE states combined was 8.56-15.63 in random survey, where as it was 34.32-56.58 in outbreaks scenario. The overall prevalence was highest in Tripura $(61.11 \%)$, followed by Assam (18.09\%), Arunachal Pradesh (15.62\%), and Meghalaya $(5.88 \%)$, when compared with other states on the basis of the number of samples received for analysis. The regional difference in the prevalence of antibodies based on the relative population has also been reported earlier [10]. In general, the low prevalence of PPR in goats in other states may be due to the topology of the region, which causes restricted movement of animals, with reduced transmission of the virus between animals. A relatively low proportion (10-30\%) of goats means that the population is at risk of infection, particularly in the NE parts of the country, as reported earlier [10]. A prevalence of PPRV antibodies ranging between 0 and $2.1 \%$ was reported previously for the north-eastern Indian states of Assam and Meghalaya [10]. However, transboundary migration of animals must be monitored for proper management of disease, especially in the border states of India. Enzooticity of the disease in the NE region, the change in virus virulence i.e., virus adaption in the goats or sheep in $\mathrm{NE}$ region, will cause increase in the number of outbreaks, as there is no vaccination of sheep and goats is undertaken at present in NE region, which in turn favours the spread of disease in that particular area.

The present survey provides only preliminary information on PPR sero-epidemiology, because the samples analysed may not be a true representation of the target population. However, the information will be very useful in the formulation of effective disease management strategies and in the implementation of a PPR vaccination programme under NCP-PPR in NE states. More systematic, intensive and comprehensive active serological surveillance programme in goats and sheep along with measurement of clinical prevalence in the enzootic areas of $\mathrm{NE}$ and then implementing intensive vaccination campaigns in these areas, must be undertaken in order to develop effective control measures/strategies for PPR.

Acknowledgments Authors wish to Indian Council of Agricultural Research (ICAR), New Delhi, India, for encouragement. The authors are grateful to the PI, AICRP collaborating centres on ADMAS for collecting and sending the samples for animal disease monitoring/ surveillance and Directors and the field veterinarians of the State Animal Husbandry Departments for their kind co-operation. The study in the form of DBT's Twining programme for the NE (F. No. BT/376/NE/TBP/2012 dated 30.11.2012) was funded by Department of Biotechnology, Government of India, New Delhi, India.

\section{References}

1. Albina E, Kwiatek O, Minet C, Lancelot R, Servan de Almeida R, Libeau G. Peste des Petits ruminants, the next eradicated animal disease? Vet Microbiol. 2013;165(1-2):38-44.

2. Anonymous. All India co-ordinated research project on animal disease monitoring \& surveillance (AICRP on ADMAS). Annual Report 2010-11. AICRP on ADMAS Collaborating Unit: Guwahati, Assam; 2011. pp. 77-78.

3. Balamurugan V, Hemadri D, Gajendragad MR, Singh RK, Rahman H. Diagnosis and control of peste des petits ruminants: a comprehensive review. Virusdisease. 2014;25(1):39-56.

4. Balamurugan V, Krishnamoorthy P, Raju DS, Rajak KK, Bhanuprakash V, Pandey AB, Gajendragad MR, Prabhudas K, Rahman $\mathrm{H}$. Prevalence of Peste-des-petits-ruminant virus antibodies in cattle, buffaloes, sheep and goats in India. Virusdisease. 2014;25(1):85-90.

5. Chaudhary D, Muthuchelvan D. De A, Yadav A.K., Sudhakar SB, Rajak KK, Pandey AB. Molecular characterization of PPR virus from an outbreak in Tripura reveals its origin from Bangladesh. In Asian -Pacific Congress of Virology (VIROCON 2013), Amity Institute of Virology and Immunology, Noida, UP. India from 17th to 20th December 2013. p. 128.

6. Chavan VV, Digraskar SU, Dhonde SN, Bedarkar SN. Seromonitoring of peste des petits ruminants (PPR) in goats (Capra hircus) of Parbhani region of Maharashtra. Vet. World. 2009;2:299-300.

7. Couacy-Hymann E, Roger F, Hurard C, Guillou JP, Libeau G, Diallo A. Rapid and sensitive detection of peste des petits ruminants virus by a polymerase chain reaction assay. J Virol Methods. 2002;100(1-2):17-25.

8. Majumder P. Studies on an incidence of peste des petits ruminants in the regional goat breeding farm at Debipur, Tripura. Indian J Anim Health. 1997;36:169-71.

9. Shaila MS, Shamaki D, Forsyth MA, Diallo A, Goatley L, Kitching RP, Barrett T. Geographic distribution of peste des petits ruminants viruses. Virus Res. 1996;43(2):149-53.

10. Singh RP, Saravanan P, Sreenivasa BP, Singh RK, Bandyopadhyay SK. Prevalence and distribution of peste des petits ruminants virus infection in small ruminants in India. Rev sci tech Off Int Epiz. 2004;23:807-19.

11. Singh RP, Sreenivasa BP, Dhar P, Bandyopadhyay SK. A sandwich-ELISA for the diagnosis of Peste des petits ruminants (PPR) infection in small ruminants using anti-nucleocapsid protein monoclonal antibody. Arch Virol. 2004;149(11):2155-70.

12. Singh RP, Sreenivasa BP, Dhar P, Shah LC, Bandyopadhyay SK. Development of monoclonal antibody based competitive ELISA for detection and titration of antibodies to peste des petits ruminants (PPR) virus. Vet Microbiol. 2004;98(1):3-15.

13. Soundararajan C, Sivakumar T, Ramesh S, Muthukrishnan S, Palanidorai R. Peste des petits ruminants among sheep and goats in an organized farm in Tamil Nadu. Indian vet. J. 2006;83(10):1045-7.

14. Swai ES, Kapaga A, Kivaria F, Tinuga D, Joshua G, Sanka P. Prevalence and distribution of peste des petits ruminants virus antibodies in various districts of Tanzania. Vet Res Commun. 2009;33:927-36

15. Thrushfield M. Veterinary Epidemiology. 3rd ed. Ames, Iowa: Blackwell Publishing Professional; 2005. 